PENGARUH MODEL PEMBELAJARAN PROBLEM BASED LEARNING (PBL) TERHADAP HASIL BELAJAR SISWA KELAS XI SEMESTER II PADA MATERI POKOK FLUIDA DINAMIK DI SMA

\author{
Yosico Indagiarmi ${ }^{1}$ dan Abd Hakim $\mathrm{S}^{\mathbf{2}}$ \\ ${ }^{1}$ Alumni Mahasiswa Program Studi Pendidikan Fisika Program \\ Pascasarjana UNIMED \\ ${ }^{2}$ Program Studi Pendidikan Fisika Program Pascasarjana UNIMED \\ email: yosicoindagiarmi@gmail.com
}

\begin{abstract}
Abstrak. Penelitian ini bertujuan untuk mengetahui pengaruh model pembelajaran Problem Based Learning terhadap hasil belajar siswa pada materi pokok fluida dinamik. Penelitian ini termasuk jenis penelitian quasi eksperimen dengan desain two group Pre-test dan Pos-test, Populasi penelitian ini adalah semua siswa kelas XI SMA Swasta Panca Budi Medan TP 2014 / 2015. Sampel penelitian ini diambil dengan teknik cluster random sampling, yang terdiri dari dua kelas, yaitu kelas eksperimen diterapkan model pembelajaran PBL, dan kelas kontrol diterapkan pembelajaran konvensional. Data penelitian ini diperoleh dengan menggunakan Instrumen berupa tes esai sebanyak 12 soal, observasi aktivitas, sikap dan keterampilan siswa. Dari analisa data untuk kelas eksperimen yang diperoleh ratarata Pre-test 30,5 dan nilai rata-rata Post-test 74,2. Kelas kontrol diperoleh rata-rata Pre-test 33,2 dan rata-rata Post-test 65,8. Kedua kelas berdistribusi normal dan memiliki variasi yang homogen. Hasil uji t postes, $t_{\text {hitung }}$ adalah 2,407 sedangkan $t_{\text {tabel }}$ adalah 2,016 pada taraf nyata 0,05 dimana $t_{\text {hitung }}>t_{\text {tabel }}$. Sehingga diperoleh bahwa ada pengaruh model pembelajaran Problem Based Learning (PBL) yang signifikan terhadap hasil belajar siswa pada materi pokok fluida dinamik kelas XI SMA Swasta Panca Budi Medan TP 2014/2015.
\end{abstract}

Katakunci: model pembelajaran, problem based learning, hasil belajar.

\title{
EFFECT OF PROBLEM BASED LEARNING MODEL LEARNING (PBL) LEARNING OUTCOMES OF CLASS XI SEMESTER II SUBJECT MATTER OF FLUID DYNAMICS IN SMA
}

\author{
Yosico Indagiarmi ${ }^{1}$ and Abd Hakim $\mathrm{S}^{\mathbf{2}}$ \\ ${ }^{1}$ Student Alumni of Physics Education Study Programs Postgraduate \\ School UNIMED \\ ${ }^{2}$ Physics Education Study Programs Postgraduate School UNIMED \\ email: yosicoindagiarmi@gmail.com
}

\begin{abstract}
This research aims to determine the effect of Problem Based Learning model on the student's learning outcomes in the subject matter dynamic fluid. This research is a quasi-experimental study with two group design Pre-test and post-test, this study population was all students of class XI SMA Private Panca Budi Medan TP 2014 / 2015. The samples were taken by cluster random sampling technique, which consists of two classes, PBL applied in
\end{abstract}


experiment class and conventional learning applied in control class, Data was obtained by using 12 essay instruments, observation of activities, attitudes and skills of students. From the analysis of the data for the experiment class gained an average of 30.5 Pre-test and the average value of Post-test 74.2. Control classes gained an average of 33.2 Pre-test and average Post-test 65.8. Both classes are normally distributed and have a homogen variation. $t_{\text {count }}$ was 2,407 and $t_{\text {table }}$ was 2,016 at the real level of 0.05 where $t_{\text {count }}>t_{\text {table. }}$. So that there is significant effect of Problem Based Learning (PBL) to student's learning result in the subject matter dynamic fluid of class XI SMA Private Panca Budi Medan TP 2014/2015.

\section{Keywords: Learning model, problem based learning, learning} outcomes

\section{PENDAHULUAN}

Pendidikan sangat erat kaitannya dengan IPTEK. Berkembangnya pendidikan sudah pasti akan berpengaruh terhadap perkembangan ilmu pengetahuan dan teknologi (IPTEK). Menurut Eldie (2013), Pesatnya perkembangan ilmu pengetahuan dan teknologi sekarang ini tidak dapat terlepas dari kemajuan ilmu fisika yang banyak menghasilkan temuan baru dalam bidang sains dan teknologi. Fisika dalam hal ini ditempatkan sebagai salah satu mata pelajaran yang penting karena salah satu syarat penguasaan ilmu pengetahuan dan teknologi berhubungan dengan ilmu pengetahuan alam (IPA) yang di dalamnya termasuk fisika. Hal ini berarti ilmu fisika memiliki peran penting dalam kemajuan IPTEK. Berdasarkan observasi awal yang dilakukan di SMA Swasta Panca Budi melalui hasil wawancara kepada salah seorang guru fisika diketahui bahwa minat siswa-siswa di SMA Swasta Panca Budi untuk belajar fisika masih rendah karena siswa-siswa ini belum paham manfaat dari pembelajaran fisika yang mereka pelajari.

Selain wawancara dengan guru mata pelajaran fisika, pembagian angket kepada siswa juga dilakukan saat observasi awal. Data yang didapat dari angket menunjukkan bahwa 55\% siswa menyatakan bahwa selama pelajaran fisika mereka tidak pernah dihadapkan dengan permasalahan yang nyata terjadi dalam kehidupannya yang berkaitan dengan materi fisika yang sedang diajarkan, 30\% menyatakan pernah tapi hanya sekali dan $15 \%$ lagi menyatakan kadang-kadang hanya pada materi tertentu saja mereka dihadapkan sengan masalah.

Berdasarkan hasil dari angket ini siswa tidak berminat belajar fisika karena tidak tahu apa kegunaan fisika bagi kehidupan mereka, mereka tidak tahu permasalahan-permasalahan apa yang bisa diselesaikan melalui fisika. Siswapun menjadi tidak aktif, tidak kreatif dan tidak inovatif dalam pembelajaran.

Berdasarkan kenyataan tersebut, dalam pembelajaran fisika perlu diterapkan suatu model pembelajaran yang sesuai. Salah satu alternatif model pembelajaran yang memungkinkan diterapkan adalah model problem based learning (PBL). Menurut Selcuk
(2010), model PBL merupakan suatu pendekatan pembelajaran dimana siswa mengerjakan permasalahan yang autentik dengan maksud untuk menyusun pengetahuan mereka sendiri, mengembangkan inkuiri dan keterampilan berpikir tingkat lebih tinggi, mengembangkan kemandirian dan percaya diri. Menurut Tasoglu (2014), pada model pembelajaran ini, peranan guru adalah menyodorkan berbagai masalah, memberikan pertanyaan, dan memfasilitasi investigasi dan dialog. Guru memberikan kesempatan kepada siswa untuk menetapkan topik masalah yang akan dibahas, walaupun sebenarnya guru telah menetapkan topik masalah apa yang harus dibahas. Menurut setyorini (2010). Hal yang paling utama adalah guru menyediakan perancah atau kerangka pendukung yang dapat meningkatkan kemampuan penyelidikan dan intelegensi siswa dalam berpikir. Proses pembelajaran diarahkan agar siswa mampu menyelesaikan masalah secara sistematis dan logis.

\section{METODE PENELITIAN}

Jenis penelitian ini adalah quasi eksperimen. Populasi dalam penelitian ini adalah semua siswa-siswi kelas XI SMA Swasta Panca Budi Medan pada semester genap T.P. 2014/2015. Dua kelas dipilih menjadi sampel penelitian dengan teknik cluster random sampling. Satu kelas eksperimen diajarkan dengan model pembelajaran dan satu kelas kontrol diajarkan dengan model pembelajaran konvensional. Variabel bebas penelitian ini adalah model pembelajaran PBL, dan variabel terikat adalah hasil belajar siswa. Desain penelitian yang digunakan adalah group pretest-postest design yang ada pada Tabel 1.

Data penelitian ini diperoleh dengan menggunakan instumen tes berupa esai, dan observasi terhadap aktivitas, sikap dan keterampilan siswa. Instrumen pengetahuan sudah divalidasi terlebih dahulu dengan menggunakan validitas isi dan validitas ramalan. Validitas isi dilakukan oleh dua orang dosen jurusan fisika UNIMED. Validitas ramalan dilakukan ke sekolah lain yang siswanya sudah pernah mempelajari materi pokok fluida dinamik ini. Observasi aktivitas, sikap, dan keterampilan dilakukan terhadap setiap siswa dan 
Y. Indagiarm dan Abd Hakim S: Pengaruh Model

Pembelajaran Problem Based Learning (PBL) terhadap

Hasil Belajar Siswa Kelas XI Semester II pada Materi

pokok Fluida Dinamik di SMA

dilakukan oleh dua orang observer.

Tabel 1. Group pre test-post test design

\begin{tabular}{|l|c|c|c|}
\hline Kelas & Pretes & Perlakuan & Postes \\
\hline Eksperimen & $\mathrm{T}_{1}$ & $\mathrm{X}$ & $\mathrm{T}_{2}$ \\
Kontrol & $\mathrm{T}_{1}$ & $\mathrm{O}$ & $\mathrm{T}_{2}$ \\
\hline
\end{tabular}

Keterangan :

$\mathrm{T}_{1}=$ Tes awal (Pre-tes)

$\mathrm{T}_{2}=$ Tes akhir (Post-tes)

$\mathrm{X}_{1}=$ Pembelajaran dengan model Problem Based Learning (PBL)

$\mathrm{X}_{2}=$ Pembelajaran dengan model konvensional

Analisa data yang digunakan untuk mengetahui pengaruh model pembelajaran PBL terhadap hasil belajar siswa pada penelitian ini adalah uji t. Sebelum uji $t$ dilakukan data penelitian haruslah normal dan homogen. Apabila Ho diterima berarti hasil belajar siswa kelas eksperimen sama dengan hasil belajar siswa kelas kontrol. Apabila Ha diterima berarti hasil belajar siswa kelas eksperimen lebih baik dari pada kelas kontrol.

\section{HASIL DAN PEMBAHASAN}

Pada awal penelitian kedua kelas diberikan tes uji kemampuan awal (pretes). Berdasarkan data hasil penelitian diperoleh nilai rata-rata pretes siswa pada kelas eksperimen sebelum diberi perlakuan dengan menggunakan model pembelajaran berbasis masalah sebesar 30,5 sedangkan pada kelas kontrol sebesar 33,2. Untuk melihat secara rinci hasil pretes kedua kelas dapat dilihat pada Gambar 1.

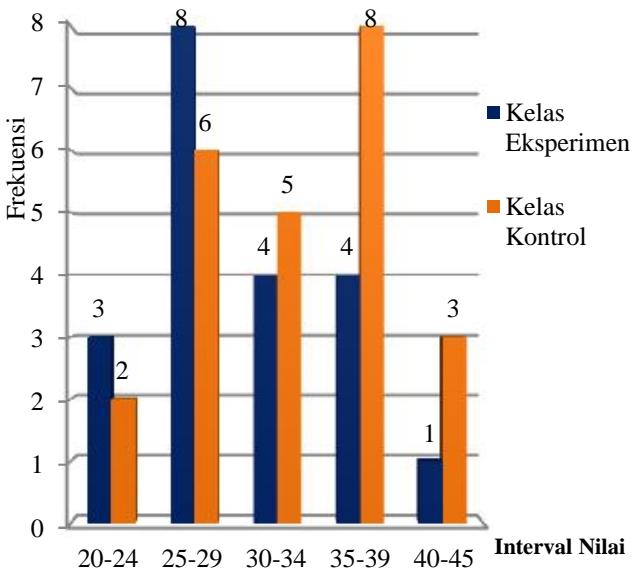

\section{Gambar 1. Diagram Batang data pretes kelas eksperimen dan kelas control}

Kedua sampel yang memiliki kemampuan awal yang sama ini, kemudian diberikan perlakuan yang berbeda, kelas eksperiman diberikan pembelajaran dengan menerapkan model pembelajaran berbasis masalah atau
Jurnal Pendidikan Fisika

p-ISSN2252-732X

e-ISSN 2301-7651

Problem Based Learning (PBL) dan di kelas kontrol diterapkan model pembelajaran konvensional. Hasil postes kedua kelas dapat dilihat secara lebih rinci pada Gambar 2.

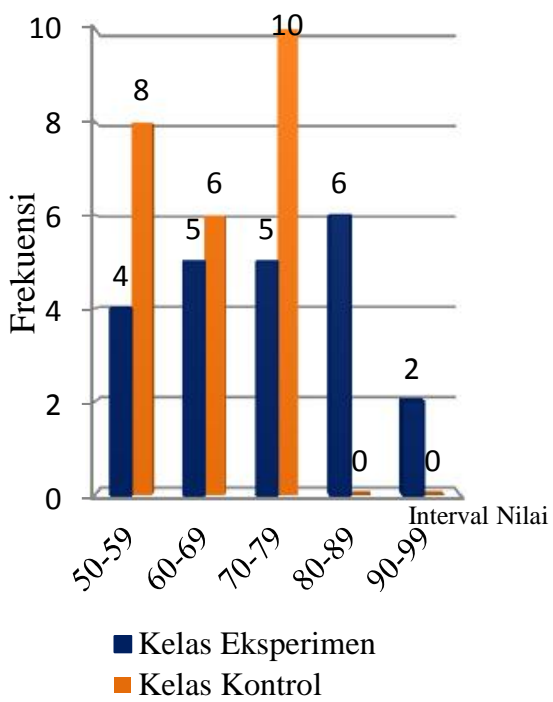

\section{Gambar 2. Diagram Batang data postes kelas eksperimen dan kelas kontrol}

Setelah memperoleh data hasil pretes siswa dari kelas eksperimen dan kelas kontrol, maka dilakukan terlebih dahulu uji asumsi data berupa uji normalitas dan uji homogenitas data pretes untuk mengetahui kelayakannya sebelum diberikan perlakuan. Hasil uji normalitas yang diperoleh dapat dilihat pada Tabel 2 dan 3.

Tabel 2. Uji Normalitas Data Pretes Kelas Eksperimen dan Kelas Kontrol

\begin{tabular}{|l|r|r|c|}
\hline \multirow{2}{*}{ Kelas } & \multicolumn{2}{|c|}{ Data Pretes } & \multirow{2}{*}{ Kesimpulan } \\
\cline { 2 - 4 } & $\mathrm{L}_{\text {hitung }}$ & $\mathrm{L}_{\text {tabel }}$ & \\
\hline Eksperimen & 0,1064 & 0,1832 & Normal \\
\hline Kontrol & 0,1016 & 0,1764 & \multirow{2}{*}{ Normal } \\
\hline Tabel 3. & $\begin{array}{l}\text { Uji Normalitas Data Postes Kelas } \\
\text { Eksperimen dan Kelas Kontrol }\end{array}$
\end{tabular}

\begin{tabular}{|l|c|c|c|}
\hline \multirow{2}{*}{\multicolumn{1}{|c|}{ Kelas }} & \multicolumn{2}{|c|}{ Data Postes } & \multirow{2}{*}{ Kesimpulan } \\
\cline { 2 - 3 } & L hitung $^{2}$ & Ltabel $_{n}$ & \\
\hline Eksperimen & 0,1795 & 0,1832 & Normal \\
\hline Kontrol & 0,1466 & 0,1764 & Normal \\
\hline
\end{tabular}

Pengujian homogenitas data dilakukan dengan uji F. Hasil uji homogenitas data yang diperoleh dapat dilihat pada Tabel 4 dan 5. 
Y. Indagiarm dan Abd Hakim S: Pengaruh Model

Pembelajaran Problem Based Learning (PBL) terhadap

Hasil Belajar Siswa Kelas XI Semester II pada Materi

pokok Fluida Dinamik di SMA

Tabel 4. Hasil Uji Homogenitas Data Pretes

\begin{tabular}{|c|c|l|l|l|}
\hline Data & Varians & Thitung & F $_{\text {tabel }}$ & Kesimpulan \\
\hline Eskperimen & 30,07 & 1,34 & 2,12 & Homogen \\
\hline Kontrol & 40,28 & & & \\
\hline
\end{tabular}

Tabel 5. Hasil Uji Homogenitas Data Postes

\begin{tabular}{|l|c|c|c|c|c|}
\hline No & Data & Varians & $\mathbf{F}_{\text {hitung }}$ & $\mathbf{F}_{\text {tabel }}$ & Kesimpulan \\
\hline 1. & eksperimen & 184,96 & \multirow{2}{*}{1,86} & 2,08 & Homogen \\
\hline 2. & kontrol & 99,59 & & & \\
\hline
\end{tabular}

Hasil uji kesamaan dapat dilihat pada Tabel 6.

Tabel 6. Hasil Uji t Pretes

\begin{tabular}{|c|c|c|c|c|}
\hline Data & $\begin{array}{l}\text { Rata- } \\
\text { rata }\end{array}$ & $t_{\text {hitung }}$ & $\mathbf{t}_{\text {tabel }}$ & Kesimpulan \\
\hline $\begin{array}{l}\text { Pretest } \\
\text { kelas } \\
\text { eksperimen }\end{array}$ & 30,5 & \multirow{2}{*}{$\begin{array}{c}1,53 \\
8\end{array}$} & \multirow{2}{*}{$\begin{array}{c}2,01 \\
6\end{array}$} & \multirow{2}{*}{\begin{tabular}{ll}
\multicolumn{2}{l}{ Kemampuan } \\
awal & siswa \\
kedua & kelas \\
sama &
\end{tabular}} \\
\hline $\begin{array}{l}\text { Pretes kelas } \\
\text { kontrol }\end{array}$ & 33,2 & & & \\
\hline
\end{tabular}

Tabel 7.

Hasil pengujian hipotesis dapat dilihat pada

Tabel 7. Hasil Uji t Postes

\begin{tabular}{|l|c|c|c|l|}
\hline Data & $\begin{array}{l}\text { Rata- } \\
\text { rata }\end{array}$ & $\mathbf{t}_{\text {hitung }}$ & $\mathbf{t}_{\text {tabel }}$ & Kesimpulan \\
\hline $\begin{array}{l}\text { Postes Kelas } \\
\text { Eksperimen }\end{array}$ & 74,2 & 2,407 & 2,016 & $\begin{array}{l}\text { Hasil belajar } \\
\text { siswa kelas } \\
\text { eksperimen } \\
\text { lebih tinggi } \\
\text { daripada hasil } \\
\text { belajar di kelas } \\
\text { kontrol. }\end{array}$ \\
\hline $\begin{array}{l}\text { Postes Kelas } \\
\text { Kontrol }\end{array}$ & 65,8 & & & \\
\hline
\end{tabular}

Perincian kategori yang dicapai siswa mulai dari pretest, aktivitas hingga postest dapat dilihat pada Gambar 3. Berikut ini ditampilkan grafik nilai pretes, nilai aktivitas dan nilai postes siswa kelas eksperimen yang disusun berdasarkan kategori yang paling rendah sampai yang paling tinggi pada Gambar 4. Persamaan linier $\mathrm{y}=\mathrm{ax}+\mathrm{b}$ memiliki nilai a yang menyatakan kemiringan garis. Jika dilihat dari grafik, pada $\mathrm{y}_{\text {post }}=1,4026 \mathrm{x}+58,238$ memiliki nilai a yang lebih besar dibandingkan dengan nilai a pada $\mathrm{y}_{\text {pre }}=0,0857 \mathrm{x}+29,629$. Pada penelitian ini $\mathrm{a}_{\text {post }}>$ $a_{\text {pre }}$, hal ini berarti nilai aktivitas mempengaruhi hasil belajar (nilai postes) atau memberi sumbangan yang besar terhadap hasil belajar dalam proses.
Jurnal Pendidikan Fisika p-ISSN2252-732X e-ISSN 2301-7651

\section{Kriteria Nilai}

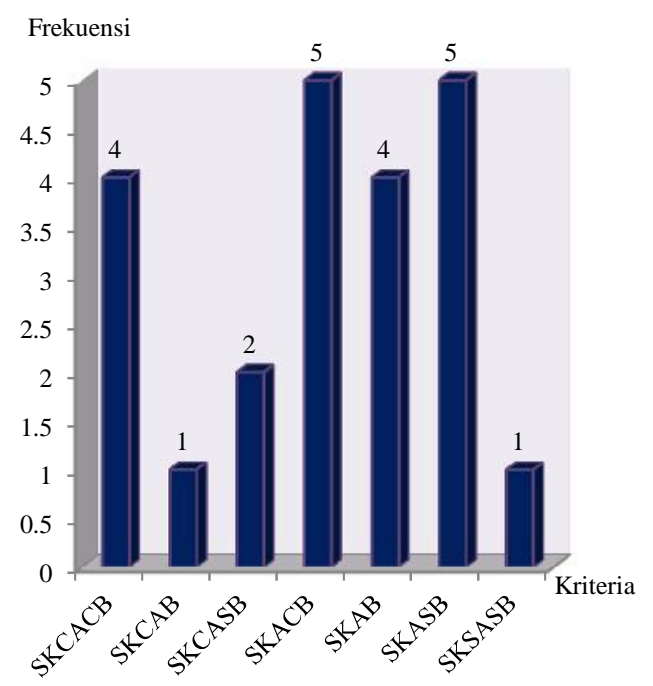

Gambar 3. Diagram batang kategori pencapaian siswa mulai dari pretest, aktivitas hingga postest

\section{Keterangan \\ SKCACB : Sangat Kurang, Cukup Aktif, \\ Cukup Baik \\ SKCAB : : Sangat Kurang, Cukup Aktif, Baik \\ SKCASB : Sangat Kurang, Cukup Aktif, \\ Sangat Baik \\ SKACB : Sangat Kurang, Aktif, Cukup Baik \\ SKAB : : Sangat Kurang, Aktif, Baik \\ SKASB : : Sangat Kurang, Aktif, Sangat Baik \\ SKSASB : Sangat Kurang, Sangat Aktif, Sangat Baik}

Berikut ini ditampilkan grafik hubungan antara nilai pretes, nilai aktivitas dan nilai postes siswa pada kelas eksperimen yang disusun berdasarkan nilai aktivitas terendah ke nilai aktivitas tertinggi. Jika dilihat dari grafik, pada $\mathrm{y}_{\text {post }}=1,1366 \mathrm{x}+61,156$ memiliki nilai a yang lebih besar dibandingkan dengan nilai a pada $\mathrm{y}_{\text {pre }}=0.127 \mathrm{x}+29,039$

. Hal ini ini berarti $a_{\text {post }}>a_{\text {pre }}$ yang berarti nilai aktivitas mempengaruhi hasil belajar (nilai postes) secara individu. Data nilai siswa perkelompok dapat disusun berdasarkan urutan nilai ratarata perkelompok dari urutan nilai rata-rata aktivitas terendah ke nilai rata-rata tertinggi. Secara lebih rinci data tersebut ditampilkan dalam gambar 6 . 
pokok Fluida Dinamik di SMA

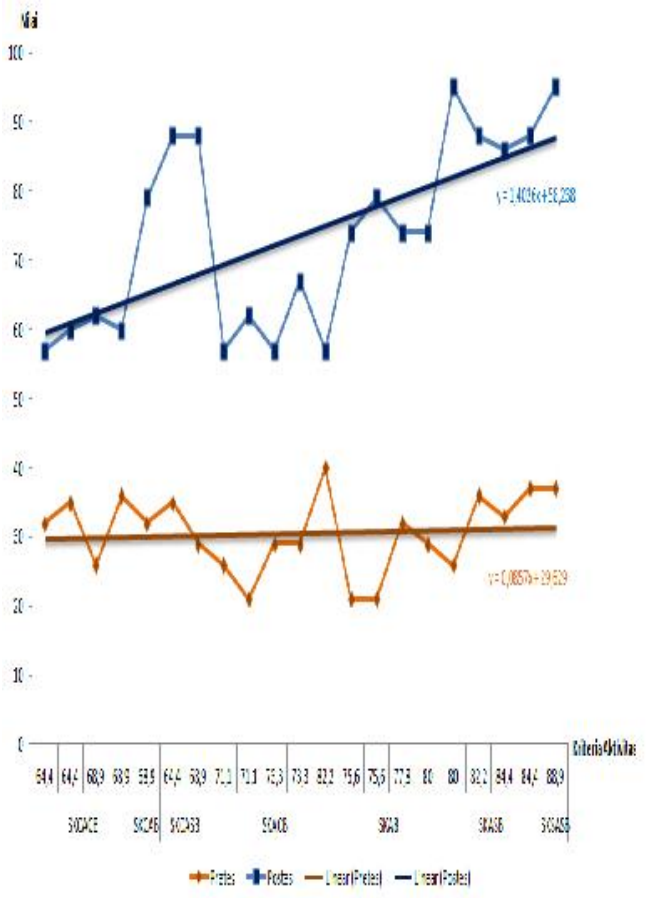

Gambar 4. Grafik nilai pretes, aktivitas dan postest berdasarakan kategori dari yang paling rendah sampai yang paling tinggi

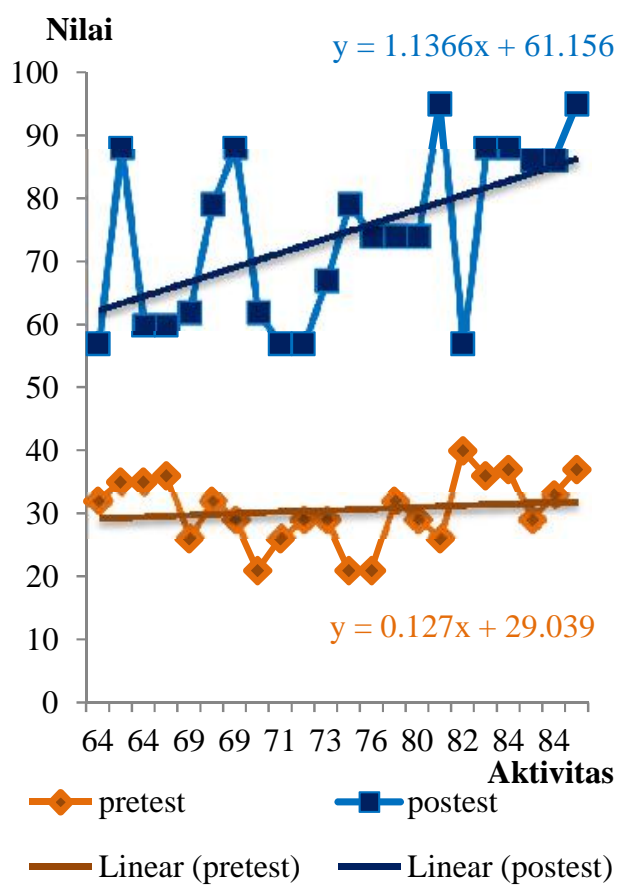

Gambar 5. Grafik nilai pretest, aktivitas dan postest berdasarkan individu

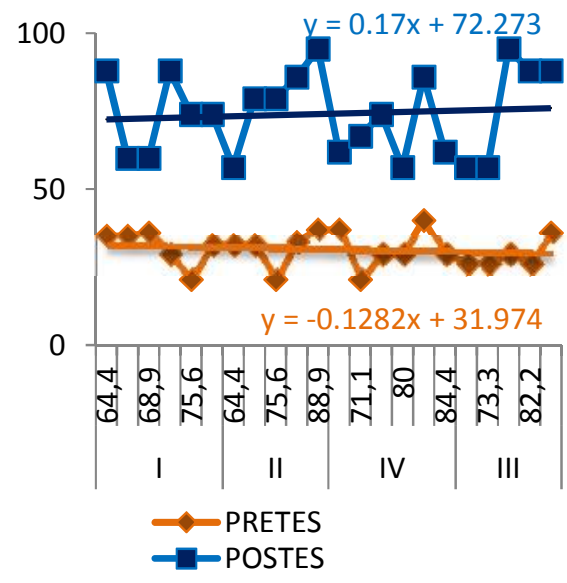

Gambar 6. Grafik nilai pretest, aktivitas dan postest berdasarkan kelompok

$$
\begin{aligned}
& \text { Jika dilihat dari grafik, pada } \\
& \mathrm{y}_{\text {post }}=0,17 \mathrm{x}+72,273 \text { memiliki nilai a yang lebih } \\
& \text { besar dibandingkan dengan nilai a pada } \\
& \mathrm{y}_{\text {pre }}=-0.1282 \mathrm{x}+31,947
\end{aligned}
$$

Hal ini berarti $a_{\text {post }}>a_{\text {pre }}$ yang berarti nilai aktivitas mempengaruhi hasil belajar (nilai postes) dalam kelompok namun pengaruhnya sangat kecil. Gambar 4, gambar 5 dan gambar 6 merupakan grafik nilai aktivitas siswa dalam proses, individu dan kelompok yang diurutkan dari nilai terendah ke tertinggi yang masingmasing memiliki persamaan linier, karena nilai $\mathrm{a}_{\text {pre }}$ pada ketiga gambar selalu lebih kecil dari pada $a_{\text {post }}$ maka pelaksanaan model pembelajaran berbasis masalah berjalan baik dan mempengaruhi hasil belajar siswa namun masih ada beberapa hal yang harus dibenahi, misalnya dalam pembagian kelompok dan pembuatan instrumen penilaian.

Hasil penelitian menunjukkan bahwa ada pengaruh model pembelajaran berbasis masalah (PBL) terhadap hasil belajar siswa pada materi fluida dinamik di Kelas XI Semester II SMA Swasta Panca Budi Medan T.P 2014/2015. Hal ini diperkuat dengan adanya perbedaan hasil belajar antara kelas eksperimen dengan kelas kontrol. Perolehan nilai rata-rata pretes siswa di kelas kontrol sebesar 33,25 dan nilai rata-rata postes sebesar 66,9 sedangkan di kelas eksperimen diperoleh nilai rata-rata pretes siswa sebesar 30,5 dan nilai rata-rata postes sebesar 74,2 .

Hasil uji normalitas untuk kedua sampel diperoleh bahwa nilai pretes dan postes berdistribusi normal dimana $\mathrm{L}_{\text {hitung }}$ tidak melebihi $\mathrm{L}_{\text {label }}$ dan berasal dari populasi yang homogen. Hasil uji kesamaan pretes menunjukkan bahwa kemampuan awal kedua kelas sama. Hasil uji hipotesis postes menggunakan uji $\mathrm{t}$ pada taraf signifikan $\alpha=0,05$ diperoleh $t_{\text {hitung }}>\mathrm{t}_{\text {tabel }}(2,407>2,016)$ yang berarti bahwa ada perbedaan hasil belajar siswa yang menggunakan model pembelajaran berbasis masalah 
(PBL) dengan model pembelajaran konvensional. Peningkatan hasil belajar menggunakan model pembelajaran berbasis masalah lebih baik disebabkan model pembelajaran ini dapat memberikan dampak positif terhadap siswa, model pembelajaran ini mampu memberikan kesempatan bagi siswa untuk lebih aktif dalam proses pembelajaran, melalui penerapan model pembelajaran berbasis masalah, siswa terlibat pada persoalannya, menemukan pemecahan masalah lewat percobaan.

\section{SIMPULAN}

Berdasarkan hasil penelitian yang didapat maka dapat diambil kesimpulan bahwa ada pengaruh model pembelajaran Problem Based Learning (PBL) terhadap hasil belajar siswa kelas XI semester II SMA Swasta Panca Budi Medan pada materi pokok fluida dinamik TP 2014/2015. Nilai rata-rata aktivitas, keterampilan dan sikap siswa di kelas eksperimen meningkat pada setiap pertemuannya sedangkan pada kelas kontrol tidak ada keterampilan yang diperoleh siswa.

\section{REFERENCES}

Eldy, E., and Sulaiman, F., (2013), Integral PBL Approach: Preliminary Findings towards Physics Students' Critical Thinking and Creative-Critical, International Journal of Humanities and Social Sience Invention, Volume 2 Issue 3, pp.18-25

Selcuk, G.S., (2010), The effects of problem-based lerning on pre-service teachers'achievement, approaches and attitudes towards lerning physics, International Journal of the Physial Sciences Vol. 5(6), pp. 711-723

Setyorini, (2010), Penerapan Model Problem Based Learning untuk Meningkatkan Kemampuan Berpikir Kritis Siswa SMP, Jurnal Pendidikan Fisika Indonesia 7 (2011):52-56

Tasoglu, A., and Bakac, M., (2014), The Effect of Problem Based Learning Approach on Conceptual Understanding in Teaching of Magnetism Topics, Eurasian Journal of Physics and Chemistry Education Vol 6(2), pp. 110-122 